\title{
High visitation rate of oil bees may increase pollination efficiency of Couepia uiti in Pantanal wetland
}

\author{
Samuel Boff ${ }^{1,2}$, Gladys F. A. Melo-De-Pinna ${ }^{3}$, Arnildo PotT $^{1}$, \\ Andréa Cardoso Araujo ${ }^{4}$ \\ ${ }^{1}$ Programa de Pós-Graduação em Biologia Vegetal, Universidade Federal de Mato Grosso do Sul, Campo Grande, Brazil \\ ${ }^{2}$ Department of Food, Environmental and Nutritional Sciences, University of Milan, Via Celoria 2, 20133, Milan, Italy \\ ${ }^{3}$ Programa de Pós-Graduação em Botânica, Universidade de São Paulo, São Paulo, Brazil \\ ${ }^{4}$ Laboratório de Ecologia, Instituto de Biociências, Universidade Federal de Mato Grosso do Sul, Campo Grande, Brazil
}

Received 6 February 2018 - Revised 27 June 2018 - Accepted 7 August 2018

\begin{abstract}
Pollen transfer to the stigma is the primary mechanism of sexual reproduction in plants. Among bee species that act as pollen vectors and pollinators, attributes such as floral visitation rate, synchrony with the receptive phase of the flower, compatibility between flower shape and foraging behavior, and morphological traits are often used to infer pollination efficiency. Herein, we evaluate visitation frequency and behavior of bee species on Couepia uiti (Chrysobalanaceae) flowers in the southern Pantanal, Brazil. Additionally, after experimental manipulation of flower visitation and by accompanying pollen tube growth in the pistil after one single visit to the flowers, we were able to pinpoint the roles of Centris spilopoda and Apis mellifera on the pollination of C. uiti. Centris spilopoda was the most important pollinator of $C$. uiti in the study area. In fact, we found that this oil bee might enhance plant reproductive success by almost $40 \%$ after a single visit. In addition to its high abundance, the efficiency of $C$. spilopoda as pollinator may be explained by its tight synchrony with pollen liberation and stigmatic receptivity of flowers of $C$. uiti.
\end{abstract}

bee activity and stigmatic receptivity / floodplain / Centridini / pollen tube / single visit

\section{INTRODUCTION}

Pollination is the mechanism whereby plants with flowers are sexually reproduced (Endress 1994; Proctor et al. 2003). For pollination to be effective (i.e., pollen tube growth occurs and reaches the ovules leading to their fertilization), pollen grains need to be transferred to stigma(s) that are reproductively compatible (Hiscock and Mcinnis 2003). Some plants are self-compatible (Brauner and Gottlieb 1987; Toräng et al. 2017),

Electronic supplementary material The online version of this article (https://doi.org/10.1007/s13592-018-0598-7) contains supplementary material, which is available to authorized users.

Corresponding author: S. Boff, samboff@gmail.com

Manuscript editor: Alexandra Klein but many species depend on xenogamic pollen for reproduction (Vilas Boas et al. 2013; Sazan et al. 2014). Xenogamic pollination, also known as cross-pollination, can influence fruit quality and seed viability (Schneider et al. 2009; ChautáMellizo et al. 2012; Stein et al. 2017).

Bees are one group of animals that are responsible for increased plant reproduction success via cross-pollination (Ollerton et al. 2011) and pollinate several species, especially in tropical areas (Endress 1994; Roubik 1989). An efficient bee pollinator may present, besides synchrony with the receptive phase of the flower, morphological characteristics that are compatible with flower shape, while flowers offer resources that are compatible with the physio-behavioral requirements of bees. Centridini bees (Hymenoptera: Apidae) have pantropical distribution (Moure et al. 2012) and present tight interaction with plants species that offer oil as 
floral resource (Vogel 1974, 1990; Vinson et al. 1997; Teixeira and Machado 2000; Martins et al. 2013). These bees are potential pollinators of several wild nectariferous and polliniferous species (e.g., Fischer and Gordo 1993; Aguiar et al. 2003; Aguiar and Gaglianone 2008), including some economically important plant crops such as Anacardium occidentale (Freitas and Paxton 1998; Holanda-Neto et al. 2002), Bertholletia excelsa (Cavalcante et al. 2018), Malpighia punicifolia and M. emarginata (Raw 1979; Oliveira and Schlindwein 2009, respectively), Passiflora alata and Solanum lycopersicum (Gaglianone et al. 2010; Gaglianone et al. 2018), Psidium guajava (Giannini et al. 2015), and Trifolium pratense (Macfarlane 2018).

Plants attract pollinators at a long distance through scents/odors as well as by the number of flowers, known as floral display. Other traits such as flower shape, flower color(s), and sugar concentration in the nectar may work as short distances attractants (e.g., Waser and Ollerton 2006; Ebeling et al. 2008). By presenting a greater floral display, plants may receive more floral visitors and, consequently, enhance fruit and seed production (Kearns and Inouye 1993; Mayfield et al. 2001). Information on fruit/seed set, as well as analysis of pollen tube growth in the style and ovary, are measurements employed to evaluate pollinator efficiency in several plant species (e.g., Motten 1986; Richards 1986; Zhang et al. 2015).

Pollen tube growth in the pistil results from the deposition of compatible pollen grains onto the stigmatic region of the flower. Despite polarized and continuing growth towards the ovule after emergence in the stigma, pollen tube growth can be interrupted a posteriori due to late acting selfincompatibility (Seavey and Bawa 1986). However, even with late incompatibility, the presence of a pollen tube indicates the pollinators' efficiency in carrying pollen to the stigma.

Couepia uiti (Mart. and Zucc.) Benth. (Chrysobalanaceae) is a self-incompatible plant species relying in cross-pollination to produce fruits (Paulino-Neto 2007). This plant species presents wide distribution in Brazil (Grandtner and Chevrette 2013), usually occurring on floodplains of small rivers and streams (Pott and Pott 1994).
In the Pantanal, which is the world's largest tropical wetland (Assine et al. 2015), it grows as a pioneer treelet, with a height of 3-6 $\mathrm{m}$ and a wide canopy that nearly reaches the ground. It flowers between August and November (Pott and Pott 1994), and fruits, which are consumed by humans (Bortolotto et al. 2018), birds, and other animal species, are produced around April-May during flood season in the Southern Pantanal. Flowers are polystemonous and uniovulate. A previous study about the breeding system of $C$. uiti reported continuous nectar production with increased sugar concentration around 10:00 am. Pollen liberation starts around 9:30 am and stigmatic receptivity at 12:00 am. Manual cross-pollination resulted in $11 \%$ fruit set (xenogamy). In natural conditions, where flowers are mostly visited by honeybees, fruit set did not exceed 15\% (Paulino-Neto 2007).

Herein, we present data about the foraging behavior of several bee species and evaluate the visitation rates of the most frequent species. Furthermore, as Couepia uiti presents several different floral visitors (Paulino-Neto 2007), we test if pollen transfer efficiency differs between two frequent bee species. To answer this question, we carried out a field experiment to evaluate the pollination success of a native solitary oil bee and the exotic eusocial honeybee by detection of pollen tube growth in the style after one single flower visit.

\section{MATERIAL AND METHODS}

\subsection{Study area}

This study was carried out in the southern Pantanal, sub-regions of Miranda and Abobral, in a partially flooded area of the Abobral river $\left(19^{\circ} 28^{\prime} 34.7^{\prime \prime} \mathrm{S}, 57^{\circ} 02^{\prime} 37.8^{\prime \prime} \mathrm{W}\right)$ where trees of C. uiti are naturally intermingled with the shrub Byrsonima cydoniifolia A. Juss. (Malpighiaceae).

Field observations took place between the 18th and 21st of October 2007 between 07:00 am and 4:00 pm. From the 16th-19th of September 2008, we carried out additional observations of the same population of $C$. uiti, but we did not evaluate visitor frequencies. During both years, field observations coincided with the end of the dry season in the area. 


\subsection{Floral visitors and pollinators}

First, flower visitors were sampled and recognized for $2 \mathrm{~h}$ during 4 days (total $8 \mathrm{~h}$ ) before starting the experiment. Once we identified the four most frequent bee species visiting the flowers, we started recording their visitation frequencies. We recorded visitation between 7:00 am and 16:00, with $10 \mathrm{~min}$ of focal observations during each hour, totaling $100 \mathrm{~min}_{\text {day }}{ }^{-1}$, and in 4 days totaling 400 min of observation.

We recorded the number of visits by female bees in permanent plots of $1 \mathrm{~m}^{2}$ at the edge of flowering trees, with the center point at the height of the observer's eyes $(1.75 \mathrm{~m})$. We only recorded female visits because floral visits by males were unclear. Males were observed taking nectar and also tried to approach females during their visits. Each flowering tree was divided into four plots, one northern, southern, eastern, and western to delimitate spatial areas where bees were recorded. Plots $(n=16)$ were marked with striped tapes. All sampled plots were assorted before sampling. The plants used for counting visitation frequencies were at least $30 \mathrm{~m}$ apart from each other. Visitation frequencies were calculated based on the number of visits without distinction between the resource (pollen or nectar) collected by the bee. To compare the total number of visits by each of the four most frequent bee species, we used KruskalWallis test, with post hoc test. To compare frequencies of those bees throughout the observation period, we used a chi-squared test. We recorded bee behavior during their visits (e.g. landing on flowers, contacting reproductive parts, collecting resources, kind of resource collected) in the field and through photographs. We categorized pollinators according to their visitation frequency and behavior as follows: Major pollinator (MP) was assigned to species which presented the highest visitation frequencies and contacted reproductive floral parts during visits; pollinator (PO) was assigned to species which contacted reproductive parts of the plants but had lower visitation frequencies than species in the previous category; and robber $(\mathrm{RO})$ to floral visitors that did not contact floral reproductive structures. All bee species were assigned to their social behavior according to Michener (1974).
After we recorded visitation and behavior, we collected bees using an entomological net. All collected specimens were killed in a jar with ethyl acetate vapor, mounted, and deposited into the zoological collection at the Universidade Federal de Mato Grosso do Sul (ZUFMS). Some specimens were deposited into the Coleção Entomológica Paulo Nogueira Neto, Departamento de Ecologia, Instituto de Biociências, Universidade de São Paulo. We also collected bees that we observed occasionally foraging on flowers of C. uiti but did not use them for frequency analysis.

\subsection{Pollen viability}

To analyze pollen viability, we used the cytoplasmic coloration method (Radford et al. 1974), using pollen grains collected at 10:00 am. We prepared five slides with the pollen of three flowers from different $C$. uiti individuals. Slides were prepared in the field using acetic carmine stain. We evaluated the percentage of viable grains (i.e. stained pollen grains) under a microscope.

\subsection{Pollination efficiency}

We performed field experiments for 4 days to evaluate the efficiency of visitors transferring pollen grains during a single visit, using the following protocol: (1) pre-anthesis flowers were bagged with non-woven pollination bags to allow floral ventilation and to prevent visitation, (2) we unbagged flowers, and (3) we allowed a single visit of a given bee (which we identified) to the flower, immediately after the visit the flower was re-bagged and tagged for analysis of pollen tube growth.

The flowers were unbagged at 12:00 am (period of stigmatic receptivity, see Paulino-Neto 2007), and single visits were recorded until 2:00 $\mathrm{pm}$. We carried out this experiment for a maximum time of $2 \mathrm{~h}$. Unvisited flowers or flowers that we were unable to evaluate bee visitation behavior were discarded. We collected experimental flowers in two periods: $24 \mathrm{~h}$ and $48 \mathrm{~h}$ after bee visitation. Flowers were sampled at two intervals to account for potential slow pollen tube growth, which could not be detected in the first $24 \mathrm{~h}$ after pollination, as well as to detect late incompatibility. Immediately after collection, flowers were 
immersed in FAA 50 (formaldehyde, acetic acid, and ethanol 50\%; Johansen 1940) and stored in ethanol $70 \%$. In the laboratory, flowers were transferred and stored in alcohol $70 \%$. Then, the pistils were isolated from the rest of the flower, placed in Beaker, and heated $\left(95^{\circ} \mathrm{C}\right)$ with alcohol $95 \%$. Afterwards, the pistil was removed from alcohol and placed in a solution of 1:1 alcohol $95 \%$ and $\mathrm{NaOH} 30 \%$ for $3 \mathrm{~min}$. on an electric heater (Dizeo de Strittmatter 1973). Pistils were then transferred to $50 \%$ bleach for clearing. After being diaphanized, pistils were placed on slides and stained with aniline blue $0.1 \%$ and then analyzed under a fluorescence microscope with light filter "A" (Martin 1958). These analyses were used to detect pollen tube growth in the pistil. Pollination efficiency (flowers with the presence of pollen tube in the style after a single visit) was compared between two visitors: the native Centris spilopoda and the exotic honeybee Apis mellifera. Frequencies of pollen tube growth from periods after flower visitation $(24 \mathrm{~h}$ and $48 \mathrm{~h}$ after flower visitation) were compared using chisquared test.

\section{RESULTS}

We recorded 14 bee species visiting the flowers of C. uiti , as well as non-identified wasps and two hummingbird species. The bees searched for both nectar and pollen in the flowers. All sampled bees belong to the family Apidae, in the following tribes: Apini, Bombini, Centridini, Ericrocidini, Meliponini, Rhathymini, and Xylocopini (Table I). Six bee species (total $42 \%$ ) belonged to Centridini, two species to Meliponini, while all other tribes had only one species (Table I). We recorded one single exotic species (Apis mellifera Linnaeus, 1758) visiting the flowers.

Table I. Bees recorded visiting flowers of Couepia uiti (Chrysobalanaceae) in southern Pantanal Miranda and Abobral regions, MS, Brazil.

\begin{tabular}{|c|c|c|c|c|c|c|}
\hline Tribe & Species & Gender & SB & Resource & Behavior & $\mathrm{KR}$ \\
\hline Apini & Apis mellifera Linnaeus 1753 & $\mathrm{~F}$ & Eusocial & $\mathrm{N} / \mathrm{P}$ & $\mathrm{PO}$ & $\mathrm{C}$ \\
\hline Bombini & Bombus sp. & $\mathrm{F}$ & $\begin{array}{l}\text { Primitively } \\
\text { eusocial }\end{array}$ & $\mathrm{N}$ & $\mathrm{PO}$ & $\mathrm{O}$ \\
\hline \multirow[t]{6}{*}{ Centridini } & Centris aenea Lepeletier, 1841 & $\mathrm{~F}$ & Solitary & $\mathrm{N}$ & $\mathrm{PO}$ & $\mathrm{O}$ \\
\hline & Centris spilopoda Moure, 1969 & $\mathrm{~F} / \mathrm{M}$ & Solitary & $\mathrm{N} / \mathrm{P}$ & MP & $\mathrm{C}$ \\
\hline & *Centris vittata Lepeletier 1841 & $\mathrm{~F} / \mathrm{M}$ & Solitary & $\mathrm{N}$ & $\mathrm{PO}$ & $\mathrm{R}$ \\
\hline & Epicharis nigrita (Friese 1900) & $\mathrm{F} / \mathrm{M}$ & Solitary & $\mathrm{N}$ & $\mathrm{PO}$ & $\mathrm{O}$ \\
\hline & *Epicharis zonata Smith 1854 & $\mathrm{~F}$ & Solitary & $\mathrm{N}$ & $\mathrm{PO}$ & $\mathrm{R}$ \\
\hline & $\begin{array}{l}\text { Epicharis xanthogastra Moure and } \\
\text { Seabra } 1959\end{array}$ & $\mathrm{~F} / \mathrm{M}$ & Solitary & $\mathrm{N} / \mathrm{P}$ & $\mathrm{PO}$ & $\mathrm{C}$ \\
\hline Ericrocidini & Mesoplia rufipes (Perty 1833) & $\mathrm{F}$ & Cleptoparasite & $\mathrm{N}$ & $\mathrm{PO}$ & $\mathrm{C}$ \\
\hline \multirow[t]{3}{*}{ Meliponini } & $\begin{array}{l}\text { Nannotrigona aff. melanocera } \\
\quad \text { (Schwarz, 1938) }\end{array}$ & $\mathrm{F}$ & Eusocial & $\mathrm{N} / \mathrm{P}$ & RO & $\mathrm{C}$ \\
\hline & Trigona spinipes (Fabricius, 1793) & $\mathrm{F}$ & Eusocial & $\mathrm{P}$ & RO & $\mathrm{O}$ \\
\hline & Paratrigona lineata (Lepeletier 1836) & $\mathrm{F}$ & Eusocial & $\mathrm{P}$ & RO & $\mathrm{O}$ \\
\hline Rhathymini & $\begin{array}{l}\text { Rhathymus bicolor Lepeletier and } \\
\text { Serville, } 1828\end{array}$ & $\mathrm{~F}$ & Cleptoparasite & $\mathrm{N}$ & PO & $\mathrm{O}$ \\
\hline Xylocopini & Xylocopa sp. & & $\begin{array}{l}\text { Facultative } \\
\text { social }\end{array}$ & $\mathrm{N}$ & $\mathrm{PO}$ & $\mathrm{O}$ \\
\hline
\end{tabular}

Gender $(\mathrm{M}=$ male, $\mathrm{F}=$ female), social behavior $(\mathrm{SB})$, floral resource $(\mathrm{N}=$ nectar, $\mathrm{P}=$ pollen $)$, and the distinction between visitors $(\mathrm{MP}=$ main pollinator, $\mathrm{PO}=$ pollinator, $\mathrm{RO}=$ robber $) ; \mathrm{KR}=$ kind of species record $(\mathrm{C}=$ recorded during censuses, $\mathrm{O}=$ occasional, $\mathrm{R}=$ rare)

*Species sampled in 2008 
Some bees visited flowers at 07:00 am when they were observed collecting nectar. At this time, bees searched for resources from non-functional flowers from the previous day or new flowers beginning anthesis. The most frequent visitors were Centris spilopoda Moure, 1969 (Centridini), followed by Epicharis xanthogastra Moure and Seabra, 1959 (Centridini), Apis mellifera (Apini), and Nannotrigona aff. melanocera Schwarz, 1938 (Meliponini) (Figure 1). Males of some bee species were also recorded foraging for nectar on the flowers of $C$. uiti during our censuses and may have occasionally acted as pollinators (Table I).

\subsection{Behavior during floral visitation}

Centris spilopoda and E. xanthogastra visited flowers by landing frontally on the reproductive structures to access the hypanthium after bending stamens and pistil laterally. During the visit, they contacted the anthers with the ventral region of the meso and metasoma, as

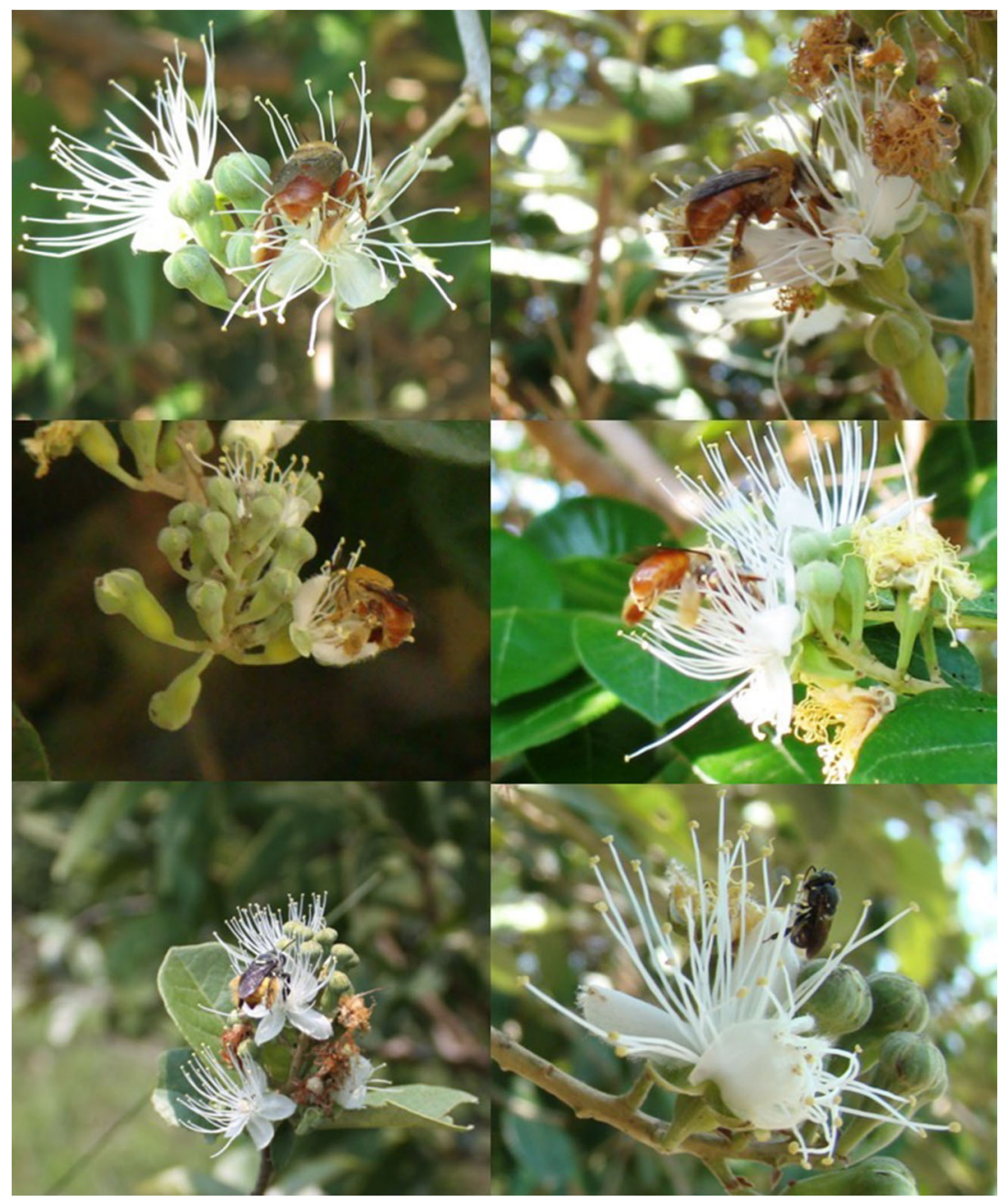

Figure 1. Pollinators and floral visitors of Couepia uiti in the Pantanal of Miranda-Abobral, Mato Grosso do Sul, Brazil. Females of C. spilopoda visiting flowers of $C$. uiti (upper and middle pictures). Female of Epicharis xanthogastra collecting nectar from the flower (bottom picture on the left side) and Nannotrigona aff. melanocera stealing pollen (bottom picture on the right side). 
well as the legs (Figure 1). Apis mellifera was observed foraging for pollen and rarely accessed the hypanthium. During visits, A. mellifera landed laterally and frontally on anthers and collected pollen grains with the first pair of legs, while walking on the anthers. Pollen grains adhered to the ventral region of the mesosoma and metasoma and transferred to the corbicula during flight. Nannotrigona aff. melanocera visited flowers by landing directly on the anthers where it collected pollen, with pollen grain transfer like honeybees. Due to its small size, the bee easily accessed the hypanthium but rarely contacted the stigmatic region. Large unidentified (species level) bees, such as Xylocopa and Bombus, were occasionally recorded above sampling plots, drinking nectar in a trap line route from plant canopies. Social behavior, role in pollination, and resources collected from flowers are summarized in Table I.

\subsection{Visiting frequency}

Among the four most frequent bee species, we recorded a total of 1061 visits to flowers of C. uiti. Over $78 \%$ of the visits were performed exclusively by $C$. spilopoda $(n=829, X=83 \pm$ 43.5 visits $\left.\mathrm{h}^{-1}\right)$, followed by $E$. xanthogastra $\left(n=134, X=13.4 \pm 12.6\right.$ visits $\left.\mathrm{h}^{-1}\right)$, A. mellifera $\left(n=67, X=6.7 \pm 7.66\right.$ visits $\left.\mathrm{h}^{-1}\right)$, and $N$. aff. melanocera $(n=31, X=3.1 \pm$ 4.93 visits $h^{-1}$ ). The overall visiting frequency was significantly different (Kruskal-Wallis test, $\left.\chi^{2}=27.177, \mathrm{df}=3, p<0.001\right)$ and frequency of Centris spilopoda significantly higher than all other pollinators $(p<0.05$, for all comparisons) (Figure 2).

Centris spilopoda presented two visitation peaks, the first at 11:00 am and the second at 14:00. Epicharis xanthogastra had the same visitation peaks as C. spilopoda, but lower frequency. Apis mellifera concentrate floral visits in the early morning. Visits by the smallest bees, $N$. aff. melanocera, were always discrete (Figure 3). Visits to flowers did not change throughout the day (from 7:00 to 16:00) within a given species (KruskalWallis test, $\chi^{2}=9$, df $=3, p=0.437$ ).

\subsection{Pollen viability and efficiency of visits}

The pollen viability after accounting 1003 pollen grains was approximately $90 \%$. Of the 40 flowers that were visited by a single

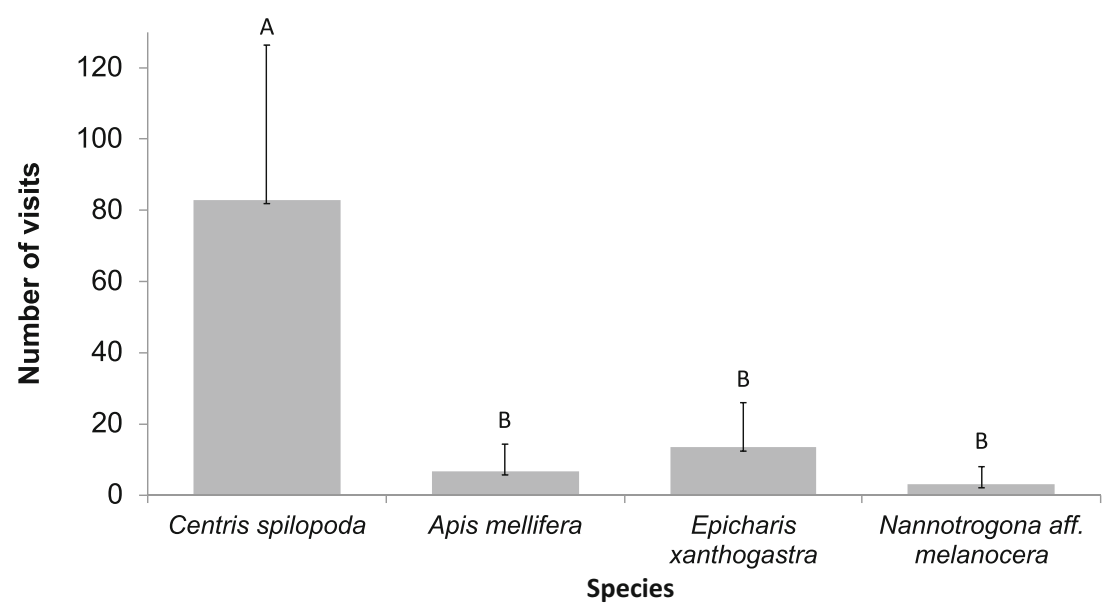

Figure 2. Number of visits of the four most frequent floral visitors (Centris spilopoda, Apis mellifera, Epicharis xanthogastra, and Nannotrigona aff. melanocera) of Couepia uiti flowers. Centris spilopoda was more frequent than all other visitors together (post hoc test, $p<0.05$ ). Different letters on the bars indicate significant differences. 


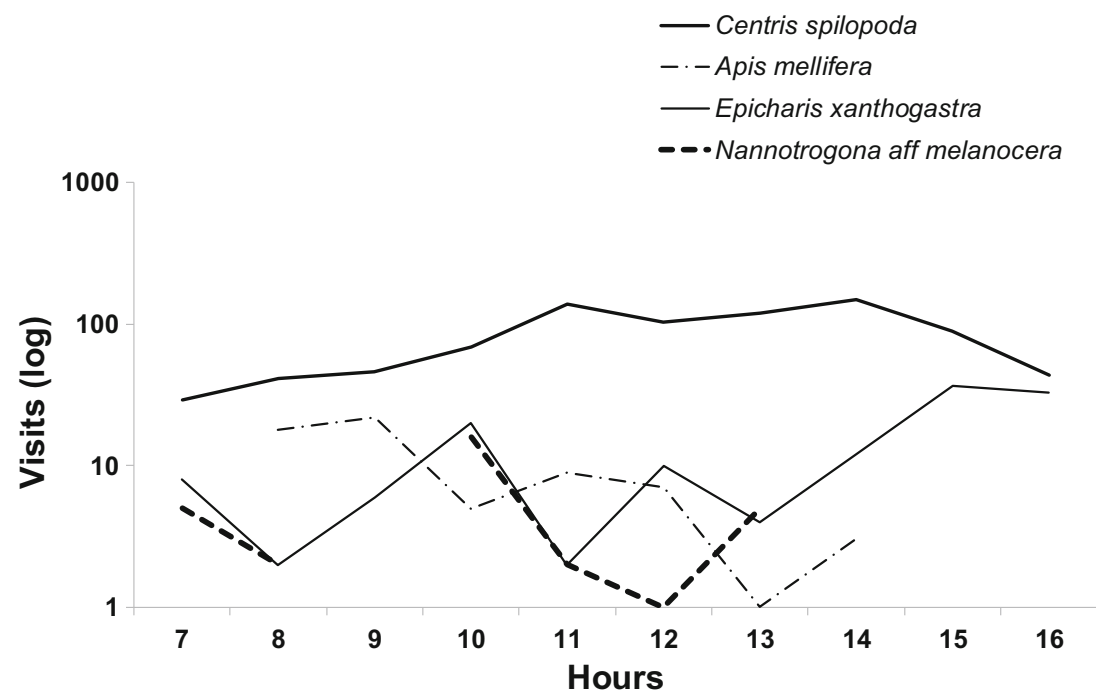

Figure 3. The visits ( $\log$ ) of the four floral visitors of Couepia uiti in 10 min periods between 7:00 and 16:00 in the Pantanal of Miranda-Abobral, MS, Brazil.

pollinator, 35 were visited by C. spilopoda, while the other five were visited by A. mellifera. We found that in 14 pistils pollen tubes grew after a single visit of $C$. spilopoda, with six in the treatment of $24 \mathrm{~h}(n=16)$ and eight after $48 \mathrm{~h}(n=19)$. None of the flowers visited by $A$. mellifera presented pollen tube growth (Table II). Pollination efficiency, however, was not significantly different across the native oil bee Centris spilopoda and the honeybee A. mellifera $\left(\chi^{2}=3.0769, \mathrm{df}=1, p=0.07941\right)$. The number of pollen tubes that grew in an interval of $24 \mathrm{~h}$ did not differ from the number

Table II. Pollen tube growth after 24 and $48 \mathrm{~h}$ (number of treated flowers) recorded for two pollinators in a single floral visitation event.

\begin{tabular}{llllll}
\hline & \multicolumn{2}{l}{ Centris spilopoda } & & \multicolumn{2}{l}{ Apis mellifera } \\
\cline { 2 - 3 } & $24 \mathrm{~h}(16)$ & $48 \mathrm{~h}(19)$ & & $24 \mathrm{~h}(3)$ & $48 \mathrm{~h}(2)$ \\
\hline PTG & $37.5 \%$ & $42 \%$ & & \\
WPT & $62.5 \%$ & $58 \%$ & & $100 \%$ & $100 \%$ \\
\hline
\end{tabular}

Note that a single visit of Centris spilopoda can increase fruit set by $40 \%$ in Couepia uiti

$P T G$ pollen tube growth, WPT without pollen tube that grew after $48 \mathrm{~h}\left(\chi^{2}=0.286, \mathrm{df}=1, p=\right.$ $0.593)$.

\section{DISCUSSION}

We found that one single visit to flowers of the self-incompatible Couepia uiti may enhance pollination. This finding may be related to speciesspecific interactions linked to the number of individuals foraging as well as to high displacement among different flowers patches. Centridini bees were the most frequent visitors to flowers of C. uiti. Due to their behavioral approach, visitation rate, and successful transfer of pollen grains to stigma, these bees were considered efficient pollinators for this plant species in our study. Centris spilopoda was the most important pollinator due to its high abundance of individuals and visitation frequency to the flowers. This oil bee presented two visitation peaks throughout the day, which coincided with an increased solute concentration of nectar and stigmatic receptivity (Paulino-Neto 2007). This species also contacted floral reproductive structures during visits promoting cross-pollination, which resulted in pollen tube growth in the pistils. We observed pollen tube growth in 14 (out of 35) flowers that were treated with a single visit. This suggests that if 
C. uiti does not have late incompatibility, fruit production can increase by $40 \%$ after one single visit by $C$. spilopoda .

Yet, A. mellifera presented lower visitation frequency, concentrated in the first hours of the morning, and probably contributes poorly to the pollination of $C$. uiti . Furthermore, this bee may negatively affect $C$. uiti reproduction since pollen removal occurs before full stigmatic receptivity at 12:00 am. For Clusia arrudae Planch. and Triana (Clusiaceae), $90 \%$ of the pollen grains were removed by $A$. mellifera, which reduced seed production (Carmo et al. 2004). Thus, pollen grain collection time by exotic bees, which occurs before full stigmatic receptivity, could cause a pollen deficit during the high foraging periods of effective pollinators, reducing fruit and seed set. Moreover, the early foraging behavior for pollen recorded in this study might also represent a case of competition with the other native bees, as A. mellifera might reduce their pollen foraging success. Pollen loss has been recognized to play an important role in nutrition of solitary bee species (Müller et al. 2006). In addition, it has been shown that depletion of resources due to foraging of honeybees affect negatively other bee species (Roubik 1978; Paini 2004; Hudewenz and Klein 2015).

Apis mellifera is known for floral constancy, generally visiting flowers that are located close together, reducing the possibility of pollen transfer between non-related individuals (Eisikowitch 1998; Karron et al. 2009). If in one hand only $15 \%$ of fruit production in natural condition has been reported to an area with high predominance of honeybees (Paulino-Neto 2007), our estimation (40\%) with native pollinator exceeds the previous values in at least 2.6 times. This visitation behavior was already indicated as negatively affecting the reproduction of some plants, especially species that depend on cross-pollination (Gibbs 1988; Camillo 1996; Sáez et al. 2014). However, in some systems, Apis mellifera may help native pollinators enhance fruit set (e.g., Freitas and Paxton 1998).

Cross-pollination, even at low rates, is considered essential to maintain populations of selfincompatible plant species (Bawa 1974). Bees of the genera Xylocopa and Bombus visited flowers of C. uiti at low frequencies, following trap line routes. Nonetheless, due to their size, the ventral portion of their bodies make broad contact with the floral reproductive structures and seem to efficiently pollinate in single visits. This pollination efficiency for the genus Xylocopa has already been recorded for $C$. uiti in the Nhecolândia sub-region of the Pantanal (Paulino-Neto 2007).

Mesoplia rufipes made few visits to the flowers of C. uiti, feeding on nectar only. According to Roubik (1989), bees of this genus are rarely found on flowers. Our record of this species and Rathymus bicolor, both cleptoparasites (Snelling 1984), visiting C. uiti flowers, may be due to the underground nests of Centris spp. and Epicharis spp. in the habitat surrounding the study area. Besides adequate soil structure for nest aggregation (SB pers. observ.), the high flux of Centridini in the area, and consequent cleptoparasites, may have been caused by the co-occurrence and simultaneous flowering of $C$. uiti and Byrsonima cydoniifolia (Malpighiaceae). The synchronized flowering of these two species provided nourishment for individuals and brood of Centridini bees, potentially making them abundant in the area. Nectar and pollen offered by C. uiti can feed adult and immature bees, and the oil offered by B. cydoniifolia flowers can be used to waterproof material to construct brood cells (Vinson et al. 2006), which is important for bees nesting in floodplain areas and for the diet of immature bees (Alves-dos-Santos et al. 2007).

\subsection{Pollen tube growth after single visits}

We recorded pollen tube growth in $40 \%$ of the 35 pistils with one single visit by $C$. spilopoda. After $24 \mathrm{~h}$ of pollen transfer to the stigma, the pollen germinated on the stigma and pollen tube growth already occurred in the pistil (see supplementary material, Fig. S1). No significant difference between the number of pollen tubes at $24 \mathrm{~h}$ and $48 \mathrm{~h}$ may indicate that this species does not present late incompatibility, or that late incompatibility occurs even later (after $48 \mathrm{~h}$ ). The limited number of pistils that presented pollen tube growth (14 out of 35) could be due to the fact that only part of pollen on visitors (C. spilopoda) originated from a non-related 
individual. Thus, low frequency of pollen tube growth could be a result of lack of pollen deposition on the stigma during the visit (pollinator inefficiency) or incompatibility between the pollen donor and receiver (Bedinger et al. 2017) potentially due to displacement behavior among flower patches. We also emphasize that ovary incompatibility (Gibbs 1988, 2014) was not evaluated since flowers were removed before fruit formation. Although the observation of pollen tube growth is an appropriate method for studying pollinator/pollen transfer efficiency (Motten 1986; Richards 1986), our findings are not conclusive regarding the effects on the reproduction success of $C$. uiti. So, high visitation frequency (or movement) of pollinators, as observed in our study, may increase the deposition of pollen grains onto the stigma (Sáez et al. 2014) and the chances of effective cross-pollination (Gorenflo et al. 2017). Since C. uiti flowers are polystemonous, they produce a large amount of pollen and, since they are uniovulate, they only need one viable pollen grain to be pollinated. We did not have evidence $(0 \%)$ of pollen tube growth from a single visit of $A$. mellifera. Our findings support the importance of native species as pollinators of xenogamous species; however, further studies are needed to clarify the pollination success mediated by native pollinators and the negative effects of the exotic A. mellifera on Couepia uiti.

Self-incompatible uniovulate flowering plants can theoretically develop fruit after non-related conspecific pollen grains are deposited onto stigmas if pollen grain and stigma are functional. Although we did not find significant differences between pollen transfers resulting in pollen tube growth in the stigma, none of the flowers visited by honeybees were pollinated. In addition, its massive foraging behavior adjusted mainly to the period of pollen presentation and before stigmatic receptivity may characterize honeybees as resource thieves, affecting negatively plant reproduction. On the other hand, C. spilopoda presented tight synchrony with stigmatic receptivity, high abundance of foragers, and therefore was the most important pollinator of Couepia uiti. In fact, we found that this oil bee might enhance plant reproductive success by almost $40 \%$ after one single visit.

\section{ACKNOWLEDGEMENTS}

The authors acknowledge Dr. Sebastião Laroca for bee identification, Amanda Galdi Boaretto, Morgana Sazan, and Waldemar Guimarães for help in the field, and the staff of the research station Base de Estudos do Pantanal (UFMS), in particular to Geraldo (in memoriam) and anonymous referees.

\section{AUTHOR CONTRIBUTIONS}

SB and ACA conceived the study and designed experiment; SB performed experiments and analysis; SB and GMP analyzed pollen tube; SB, AP, and ACA led the writing of the study. All authors read and approved the final manuscript.

\section{COMPLIANCE WITH ETHICAL STANDARDS}

Conflict of interest The authors declare that they have no conflict of interest.

Un taux de fréquentation élevé des abeilles à huile peut augmenter l'efficacité de la pollinisation de Couepia uiti dans les zones humides du Pantanal

Activité des abeilles et réceptivité stigmatique, plaine inondable, Centridini, tube pollinique, visite unique

Hohe Visitationsrate von Ölbienen könnte die Bestäubungseffizienz an Coupeia uiti in Feuchtgebiete vom Pantanal erhöhen

Bienenaktivität und Aufnahmefähigkeit des Stigmas, Überschwemmungsgebiet, Centridini, Pollenschläuche, Einzelbesuche

\section{REFERENCES}

Aguiar, W. M., Gaglianone, M. C. (2008) Comportamento de abelhas visitantes florais de Lecythis lurida (Lecythidaceae) no norte do estado do Rio de Janeiro. Rev. Bras. Entomol. 52 (2), 277-282

Aguiar, C. M. L., Zanella, F. C. V., Martins, C. F., Carvalho, C. A. L. (2003) Plantas visitadas por Centris spp. (Hymenoptera: Apidae) na caatinga para obtenção de recursos florais. Neotrop. Entomol. 32, 247-259 
Alves-dos-Santos, I., Machado, I. C., Gaglianone, M. C. (2007) História natural das abelhas coletoras de óleo. Oecol. Bras. 11 (4), 242-255

Assine, M. L., Merino, E. R., Pupim, F. D. N., Macedo, H. D. A., Santos, M. G. M. D. (2015) The Quaternary alluvial systems tract of the Pantanal Basin, Brazil. Braz. J. Geol. 45 (3), 475-489

Bawa, K. S. (1974) Breeding systems of tree species of a lowland tropical community. Evolution 28 (1), 85-92

Bedinger, P. A., Broz, A. K., Tovar-Mendez, A., McClure, B. (2017) Pollen-pistil interactions and their role in mate selection. Plant Physiol. 173 (1), 79-90. https://doi.org/10.1104/pp.16.01286

Bortolotto, I. M., Damasceno-Junior, G. A., Souza, P. R., Pott, A. (2018) Lista preliminar das plantas alimentícias nativas de Mato Grosso do Sul, Brasil. Iheringia Série Botânica 31, 101-116. (https://isb. emnuvens.com.br/iheringia/article/view/683)

Brauner, S., Gottlieb, L. (1987) A self-compatible plant of Stephanomeria exigua subsp. Coronaria (Asteraceae) and its relevance to the origin of its self-pollinating derivative $S$. malheurensis. Syst. Bot. 12 (2), 299304. https://doi.org/10.2307/2419325

Camillo, E. (1996) Utilização de espécies de Xylocopa (Hymenoptera, Anthophoridae) na polinização do maracujá amarelo.p.141-146. in: Anais do II Encontro sobre abelhas. Ribeirão Preto Universidade de São Paulo, Faculdade de Filosofia, Ciências e Letras de Ribeirão Preto

Carmo, R. M., Villaron Franceschinelli, E., da Silveira, F. A. (2004) Introduced honeybees (Apis mellifera) reduce pollination success without affecting the floral resource taken by native pollinators. Biotropica $\mathbf{3 6}$ (3), 371-376

Cavalcante, M. C., Galetto, L., Maués, M. M., Pacheco Filho, A. J. S., et al. (2018) Nectar production dynamics and daily pattern of pollinator visits in Brazil nut (Bertholletia excelsa Bonpl.) plantations in Central Amazon: implications for fruit production. Apidologie. https://doi.org/10.1007/s13592-018-0578-y

Chautá-Mellizo, A., Campbell, S. A., Bonilla, M. A. (2012) Effects of natural and artificial pollination on fruit and offspring quality. Basic Appl. Ecol., Jena, 13 (6), 524-532

Grandtner, M. M, Chevrette, J. (2013) Dictionary of Trees, Volume 2: South America: Nomenclature, Taxonomy and Ecology. Academic Press.

Dizeo de Strittmatter, C. G. (1973) Nueva técnica de diafanización. Bol. Soc. Argent. Bot. 15, 126-9

Ebeling, A., Klein, A.M., Schumacher, J., Weiser, W.W., Tscharntke, T. (2008) How does plant richness affect pollinator richness and temporal stability of flower visits? Oikos 177 (12), 1808-1815

Eisikowitch, D. (1998) Mobility of honey bee (Apidae, Apis mellifera L.) during foraging in avocado orchard. Apidologie 29 (3), 209-219

Endress, P. K. (1994) Diversity and evolutionary biology of flowers. Cambridge: Cambridge University Press.
Fischer, E., Gordo, M. (1993) Qualea cordata, pollination by the territorial bee Centris tarsata in the Campos Rupestres, Brazil. Ciência e Cultura (SBPC) 45 (2), 144-147

Freitas, B. M., Paxton, R. J. (1998) A comparison of two pollinators: the introduced honey bees Apis mellifera and an indigenous bee Centris tarsata on cashew Anacardium occidentale in its native range of $\mathrm{NE}$ Brazil. J. Appl. Ecol. 35 (1), 109-121

Gaglianone, M. C., Rocha, H. H. S., Benevides, C. R., Junqueira, C. N., Augusto, S. C. (2010) Importância de Centridini (Apidae) na polinização de plantas de interesse agrícola: o maracujá-doce (Passiflora alata Curtis) como estudo de caso na região sudeste do Brasil. Oecol. Austral. 14 (1), 152-164

Gaglianone, M.C., Franceschinelli, E.V., Oliveira Campos, M. J., Freitas, L., et al. (2018) Applied pollination in temperate and subtropical areas, in: Roubik D.W. (Ed.), The pollination of cultivated plants. A compendium for practitioners Vol 1. Edition: Second Edition. Chapter: 9.3.4. Food and Agriculture Organization of the United Nations (FAO), pp. 238-247

Giannini, T. C., Boff, S., Cordeiro, G. D., Cartolano Jr. E. A., Veiga, A. K., Imperatriz-Fonseca V. L., Saraiva A. M. (2015) Crop pollinators in Brazil, a review of reported interactions. Apidologie 46 (2), 209-223

Gibbs, P. E. (1988) Self-incompatibility mechanisms in flowering plants; some complications and clarifications. Lagascalia 15 (1), 17-28

Gibbs P. E. (2014) Late-acting self-incompatibility-the pariah breeding system in flowering plants. New Phytol. 203 (3), 717-734

Gorenflo, A., Diekötter, T., van Kleunen, M., Wolters, V., Jauker, F. (2017) Contrasting pollination efficiency and effectiveness among flower visitors of Malva sylvestris, Borago officinalis and Onobrychis viciifolia. J. Pollinat. Ecol. 21 (1), 62-70

Hiscock, S. J., Mcinnis, S. M. (2003) Pollen recognition and rejection during the sporophytic selfincompatibility response: Brassica and beyond. Trends Plant Sci. 8 (12), 606-613

Holanda-Neto, J. P., Freitas, B. M., Bueno, D. M., Araújo, Z. B. (2002) Low seed/nut productivity in cashew (Anacardium occidentale): Effects of selfincompatibility and honey bee (Apis mellifera) foraging behaviour. J. Hortic. Sci. Biotechnol. 77 (2), 226-231

Hudewenz, A., Klein, A. M. (2015) Red mason bees cannot compete with honey bees for floral resources in a cage experiment. Ecol. Evol. 5 (21), 5049-5056. https://doi.org/10.1002/ece3.1762

Johansen, D. A. (1940) Plant microtechnique. McGraw Hill Book Co. Inc., New York.

Karron, J. D., Holmquist K.G., Flanagan R.J., Mitchell, R. J. (2009) Pollinator visitation patterns strongly influence among-flower variation in selfing rate. Ann. Bot. (Lond) 103 (9), 1379-1383

Kearns, C. A., Inouye D. W. (1993) Techniques for pollination biologists. University Press of Colorado. 
Macfarlane R. P. (2018) Applied pollination in temperate and subtropical areas, in: Roubik D.W. (Ed.), The pollination of cultivated plants. A compendium for practitioners Vol 1. Edition: Second Edition. Chapter: 8.11.5. Food and Agriculture Organization of the United Nations (FAO), pp. 137-181

Martin, F. W. (1958) Staining and observing pollen tubes in the styles by means of fluorescence. Stain Technol. 34 (3) , 125-128

Martins, A. C., Aguiar, A. J., Alves-dos-Santos, I. (2013) Interaction between oil-collecting bees and seven species of Plantaginaceae. Flora, 208 (7), 401-411

Mayfield, M., Waser, N. M., Price, M. (2001) Exploring the 'Most effective pollinator principle' with complex flowers bumblebees and Ipomopsis aggregata. Ann. Bot. 88 (4), 591-96

Michener, C. D. (1974) The social behavior of the bees. Cambridge: Harvard University Press.

Motten, A. F. (1986) Pollination ecology of the spring wildflower community of a temperate deciduous forest. Ecol. Monogr. 56 (1), 21-42

Moure, J. S., Urban, D., Melo, G. A. R. (2012) Catalogue of Bees (Hymenoptera, Apoidea) in the Neotropical Region (Moure, Urban, Melo, Orgs,). online version. Disponível em: http://www.moure.cria.org. br/catalogue (acessado em 3 de outubro de 2012)

Müller, A., Diener, S., Schnyder, S., Stutz, K., Sedivy, C.; Dorn, S., (2006) Quantitative pollen requirements of solitary bees: implications for bee conservation and the evolution of bee-flower relationships. Biol. Conserv. 130 (4), 604-615. https://doi.org/10.1016/j. biocon.2006.01.023

Oliveira, R., Schlindwein, C. (2009) Searching for a manageable pollinator for acerola orchard: The solitary oilcollecting bee Centris analis (Hymenoptera: Apidae: Centridini). J. Econ. Entomol. 102 (1), 265-273

Ollerton, J., Winfree, R., Tarrant, S. (2011) How many flowering plants are pollinated by animals? Oikos 120 (3), 321-326. https://doi.org/10.1111/j.16000706.2010.18644.x

Paini, D. R. (2004) Impact of the introduced honey bee (Apis mellifera) (Hymenoptera: Apidae) on native bees: a review. Austral Ecol. 29 (4), 399-407. https://doi.org/10.1111/j.1442-9993.2004.01376.x

Paulino-Neto, H. F. (2007) Pollination and the breeding system of Couepia uiti (Mart and Zucc) Benth. (Chrysobalanaceae) in the Pantanal da Nhecolândia. Braz. J. Bot. 67 (4), 715-719

Pott, A., Pott, V. J. (1994) Plantas do Pantanal. Brasília, Embrapa.

Proctor, M., Yeo, P., Lack, A. (2003) The natural history of pollination. Timber Press. Portland.

Radford, A. E., Dickison, W. C. Massey, J. R., Bell, C. R. (1974) Vascular plant systematics. New York: Harper and Row Publishers.

Raw, A. (1979) Centris dirrhoda (Anthophoridae), the bee visiting west indian cherry flowers (Malpighia punicifolia). Rev. Biol. Trop. 27 (2), 203-205.
Richards, A. J. (1986) Plant Breeding Systems. Allen and Unwin, London.

Roubik, D.W. (1978) Competitive interactions between neotropical pollinators and africanized honey bees. Science 201 (4360), 1030-1032. https://doi. org/10.1126/science.201.4360.1030

Roubik, D. W. (1989) Ecology and natural history of tropical bees. Cambridge: Cambridge University Press.

Sáez, A., Morales, C. L., Ramos, L. Y., Aizen, M. A. (2014) Extremely frequent bee visits increase pollen deposition but reduce drupelet set in raspberry. J. Appl. Ecol. 51 (6), 1603-1612. https://doi.org/10.1111/13652664.12325

Sazan, M. S., Bezerra, A. D. M., Freitas, B. M. (2014) Oil collecting bees and Byrsonima cydoniifolia A. Juss. (Malpighiaceae) interactions: the prevalence of long-distance cross pollination driving reproductive success. An. Acad. Bras. Ciên. 86 (1), 347-358

Schneider, D., Goldway, M., Rotman, N., Adato, I., Stern, R.A. (2009) Cross pollination improves 'Orri' mandarin fruit yield. Sci. Hortic. 122 (3), 380-384

Seavey, S. R., Bawa K. S. (1986) Late-acting self-incompatibility in Angiosperms. Bot. Rev. 52 (2), 95-219

Snelling, R. R. (1984) Studies on the taxonomy and distribution of American Centridine bees (Hymenoptera: Anthophoridae). Natural History Museum Los Angeles County, CA., Contrib. Sci. (Los Angeles). 347, 1-69

Stein, K., Coulibaly, D., Stenchly, K., Goetze, D., Porembski, S., Lindner, A., Konaté S, Linsenmair, E. K. (2017) Bee pollination increases yield quantity and quality of cash crops in Burkina Faso, West Africa. Sci. Rep. 7 (1), 17691

Teixeira, L. A. G., Machado, I. C. (2000) Sistema de polinização e reprodução Byrsonima sericea DC. (Malpighiaceae). Acta Bot. Bras. 14 (3), 347-357

Toräng P., Vikström L., Wunder J., Wötzel S., Coupland G., Ågren J. (2017) Evolution of the selfing syndrome: Anther orientation and herkogamy together determine reproductive assurance in a selfcompatible plant. Evolution 71 (9), 2206-2218

Vilas Boas, J. C., Fava, W. S., Laroca, S., Sigrist, M. R. (2013) Two sympatric Byrsonima species (Malpighiaceae) differ in phenological and reproductive patterns. Flora 208 (5-6), 360-369

Vinson, S. B., William, H. J., Frankie, G. W., Shrum, G. (1997) Floral lipid chemistry of Byrsonima crassifolia (Malpighiaceae) and a use of floral lipids by Centris bees (Hymenoptera: Apidae). Biotropica 29 (1), 76-83

Vinson, S. B., Frankie, G. W., Williams, H. J. (2006) Nest liquid resources of several cavity nesting bees in the genus Centris and the identification of a preservative, levulinic acid. J. Chem. Ecol. 32 (9), 2013-2021

Vogel, S. (1974) Ölblumen und Ölsammelnde Bienen. Trop. Subtrop. Pflanzenwelt 7, 1-267 
Vogel, S. (1990) History of the Malpighiaceae in the light of pollination ecology. Mem. N. Y. Bot. Gard. 55, 130-142.

Waser, N. M., Ollerton, J. (2006) Plant-pollinator interactions: from specialization to generalization. (Waser Ollerton, J. Eds.). University of Chicago Press.
Zhang H., Huang J., Williams P. H., Vaissière, B. E., Zhou, Z., Gai, Q., et al. (2015) Managed bumblebees outperform honeybees in increasing peach fruit set in China: Different limiting processes with different pollinators. PLoS ONE 10 (3), e0121143. https://doi.org/10.1371 /journal.pone.0121143 